\title{
Synthesis of Silica-supported Nanoiron for Cr(VI) Removal: Application of Box-Behnken Statistical Design (BBD)
}

(Sintesis Besi Nano Disokong Silika untuk Penyingkiran Cr(VI): Aplikasi Reka Bentuk Statistik Box-Behnken (BBD))

\author{
PRAEWPATRA ARCHARIYAPANYAKUL, BHUCKCHANYA PANGKUMHANG, \\ PUMMARIN KHAMDAHSAG \& VISANU TANBOONCHUY*
}

\begin{abstract}
This study aimed to optimize the condition of silica-supported nanoscale zero valent iron (NZVI/SiO ${ }_{2}$ ) synthesis by colloidal impregnation method. Box-Behnken design (BBD) was used as a tool to create and analyze the 17 synthesized conditions of $\mathrm{NZVI} / \mathrm{SiO}_{2}$ samples. The independent variables included ethanol concentration (0-100 vol\%), amount of silica (0.025-0.125 g) and agitation speed (100-400 rpm). In addition, analysis of variance (ANOVA) for a response surface quadratic model was used to approximate statistical relationship of independent variables. The reducing performance of the synthesized $\mathrm{NZVI} / \mathrm{SiO}$, was examined through removal of $\mathrm{Cr}(\mathrm{VI})$ contaminated in water. The optimum of NZVI/SiO synthesis was validated with 100 vol\% of ethanol concentration, $0.075 \mathrm{~g}$ of silica amount, and 100 rpm of agitation speed. The materials were characterized using X-ray diffraction (XRD), scanning electron microscopy with energy dispersive X-ray spectroscopy (SEM-EDX), and nitrogen adsorption/desorption which showed the existence of NZVI phase, composition, and morphology. The $\mathrm{Cr}(\mathrm{VI})$ removal efficiency of the $\mathrm{NZVI} / \mathrm{SiO}_{2}$ was tested further at the solution $\mathrm{pH} 4,7$ and 10 in comparison with that by pristine NZVI and silica-unsupported NZVI $\left(\mathrm{NZVI}+\mathrm{SiO}_{2}\right)$. Among the three materials, $\mathrm{NZVI} / \mathrm{SiO}{ }_{2}$ presented the highest $\mathrm{Cr}(\mathrm{VI})$ removal, especially at $\mathrm{pH} 7$ and 10 with 98 and $94.41 \%$, within 60 min. This was due to the adsorption of $\mathrm{Cr}(\mathrm{OH})_{3}$ and $\mathrm{Fe}(\mathrm{OH})_{3}$ precipitates over $\mathrm{SiO}_{2}$ resulting in availibilty of $\mathrm{NZVI} / \mathrm{SiO}{ }_{2}$ 's active sites. The proposed mechanism of $\mathrm{Cr}(\mathrm{VI})$ removal by $\mathrm{NZVI} / \mathrm{SiO}_{2}$ was also described.
\end{abstract}

Keywords: Box-Behnken design; chromium; NZVI; silica-supported nanoiron

\section{ABSTRAK}

Kajian ini bertujuan untuk mengoptimumkan keadaan sintesis besi skala nano disokong silika bervalensi sifar (NZVI/ $\mathrm{SiO}_{2}$ ) melalui kaedah pemadatan koloid. Reka bentuk Box-Behnken (BBD) telah digunakan sebagai alat untuk mencipta dan menganalisis sampel 17 keadaan sintesis NZVI/SiO . Pemboleh ubah bebas termasuk kepekatan etanol (0-100 vol\%), silika (0.025-0.125 g) dan kelajuan goncangan (100-400 rpm). Selain itu, analisis varians (ANOVA) untuk model quadratik tindak balas permukaan telah digunakan untuk menganggar hubungan statistik pemboleh ubah bebas. Pengurangan prestasi sintesis $\mathrm{NZVI} / \mathrm{SiO}_{2}$ telah disemak melalui penyingkiran $\mathrm{Cr}$ (VI) tercemar dalam air. Sintesis $\mathrm{NZVI/SiO}{ }_{2}$ optimum telah disahkan dengan 100 vol\% kepekatan etanol, $0.075 \mathrm{~g}$ silika dan $100 \mathrm{rpm}$ kelajuan goncangan. Bahan ini telah dicirikan menggunakan pembelauan sinar-x (XRD), mikroskop elektron imbasan dengan spektroskopi tenaga serakan sinar-x (SEM-EDX) dan nitrogen penjerapan/penyahjerapan yang menunjukkan kewujudan fasa NZVI, komposisi dan morfologi. Kecekapan penyingkiran $\mathrm{Cr}(\mathrm{VI}) \mathrm{NZVI/SiO}$, telah diuji selanjutnya pada larutan $\mathrm{pH} 4,7$ dan 10 berbanding dengan NZVI asli dan NZVI tidak disokong silika ( $\mathrm{NZVI}_{2} \mathrm{SiO}_{2}$ ). Antara ketiga-tiga bahan, NZVI/SiO ${ }_{2}$ menunjukkan penyingkiran Cr(VI) tertinggi, terutamanya pada pH 7 dan 10 dengan 98 dan $94.41 \%$ dalam masa 60 minit. Ini disebabkan penjerapan $\mathrm{Cr}(\mathrm{OH})_{3}$ dan mendakan $\mathrm{Fe}(\mathrm{OH})_{3}$ ke atas $\mathrm{SiO}_{2}$ yang mengakibatkan ketersediaan tapak aktif $\mathrm{NZVI} / \mathrm{SiO}_{2}$. Mekanisme cadangan penyingkiran $\mathrm{Cr}(\mathrm{VI})$ oleh $\mathrm{NZVI} / \mathrm{SiO}_{2}$ turut dibincangkan.

Kata kunci: Besi nano disokong silika; kromium; NZVI; reka bentuk Box-Behnken

\section{INTRODUCTION}

Modification of nanoscale zero valent iron (NZVI) is one of the most important ways to improve the removal efficiency of chromium contaminated in water (Fu et al. 2016; Li et al. 2016; Shih et al. 2015; Toli et al. 2016; Wu et al. 2015; Yirsaw et al. 2016; Zhou et al. 2015). Since chromium is widely applied in several kinds of industrial work such as metallurgy, industrial dyes, paint pigments, chrome tanning and electroplating operations, it is mostly found in industrial wastewater (Liu et al. 2016; Padmavathy et al. 2016). In addition, chromium could be found in groundwater in regard to leaching from contaminated soil in mine (Coller-Myburgh et al. 2014). Due to its toxicity and carcinogenicity, the World Health Organization (WHO) has set a drinking water limit for chromium of $0.05 \mathrm{mg} / \mathrm{L}$ (WHO 2004). In order to avoid contamination of chromium 
in natural water sources used for public supply, the removal of chromium from industrial wastewater and groundwater become necessary.

Generally, chromium exists in water in two oxidation states including $\mathrm{Cr}$ (III) and $\mathrm{Cr}(\mathrm{VI})$. However, $\mathrm{Cr}(\mathrm{VI})$ compounds are categorized as carcinogen and was confirmed to be 10- to 1000-fold more toxic than $\mathrm{Cr}$ (III) compounds (Katz et al. 1993). With the high water solubility of $\mathrm{Cr}(\mathrm{VI})$, it readily diffuses in the environment and accumulates in living cells (Anderson 1997; Costa 2003).

In conventional techniques, $\mathrm{Cr}(\mathrm{VI})$ is firstly reduced to $\mathrm{Cr}(\mathrm{III})$ using a chemical reducing agent, like $\mathrm{NaHSO}_{3}$, that reduces $\mathrm{Cr}(\mathrm{VI})$ to $\mathrm{Cr}(\mathrm{III})$ in the form of $\mathrm{Cr}_{2}\left(\mathrm{SO}_{4}\right)_{3}$. Afterwards, the reduced $\mathrm{Cr}(\mathrm{VI})$ can be removed as insoluble $\mathrm{Cr}(\mathrm{OH})_{3}$ by precipitation using a coagulating agent, such as $\mathrm{NaOH}$. The chemical equation is given in (1) and (2) (Chang et al. 2005, 2003; Chen et al. 2006; Guha $\&$ Bhargava 2005). Consequently, the treatment requires a significant amount of reducing and coagulating agent.

$$
\begin{aligned}
& 4 \mathrm{H}_{2} \mathrm{CrO}_{4}+6 \mathrm{NaHSO}_{3}+3 \mathrm{H}_{2} \mathrm{SO}_{4} \rightarrow 2 \mathrm{Cr}_{2}\left(\mathrm{SO}_{4}\right)_{3} \\
& +3 \mathrm{Na}_{2} \mathrm{SO}_{4}+10 \mathrm{H}_{2} \mathrm{O} . \\
& \mathrm{Cr}_{2}\left(\mathrm{SO}_{4}\right)_{3}+6 \mathrm{NaOH} \rightarrow 2 \mathrm{Cr}(\mathrm{OH})_{3(\mathrm{~s})}+3 \mathrm{Na}_{2} \mathrm{SO}_{4} .
\end{aligned}
$$

Recently, there was considerable interest in using NZVI to treat $\mathrm{Cr}$ (VI) contaminated in groundwater (Chang 2003). In this process, NZVI $\left(\mathrm{Fe}^{0}\right)$ acts as a reducing agent or an electron donor, while $\mathrm{CrO}_{4}{ }^{2-}$ acts as reducible species or an electron acceptor, which is shown in (3) and (4) (Wu et al. 2015),

$$
\begin{aligned}
& \mathrm{Fe}^{0}+\mathrm{CrO}_{4}^{2-}+4 \mathrm{H}_{2} \mathrm{O} \rightarrow \mathrm{Fe}(\mathrm{OH})_{3(\mathrm{~s})}+ \\
& \mathrm{Cr}(\mathrm{OH})_{3(\mathrm{~s})}+2 \mathrm{OH}^{-} . \\
& 1-x \mathrm{Fe}(\mathrm{OH})_{3(\mathrm{~s})}+x \mathrm{Cr}(\mathrm{OH})_{3(\mathrm{~s})} \rightarrow \mathrm{Cr}_{x} \mathrm{Fe}_{1-x}(\mathrm{OH})_{3(\mathrm{~s})} .
\end{aligned}
$$

The reaction between $\mathrm{Fe}(\mathrm{OH})_{3(\mathrm{~s})}$ and $\mathrm{Cr}(\mathrm{OH})_{3(\mathrm{~s})}$ generated from the reduction of $\mathrm{Cr}(\mathrm{VI})$ using NZVI can produce $\mathrm{Cr}_{x} \mathrm{Fe}_{1-x}(\mathrm{OH})_{3}$ that has a low water solubility and readily precipitates (Sass \& Rai 1987). Therefore, one advantage in using NZVI is that a coagulant is no longer needed. However, the efficiency of $\mathrm{Cr}(\mathrm{VI})$ reduction is decreased as the solution $\mathrm{pH}$ increases while the NZVI's surface might be blocked by the precipitated forms of $\mathrm{Cr}_{x} \mathrm{Fe}_{1-x}(\mathrm{OH})_{3}$ or $\mathrm{Fe}(\mathrm{OH})_{3}$ (Wu et al. 2015). In order to prevent the blockage of undesired adsorptive substrates onto NZVI, not only decreasing of the solution $\mathrm{pH}$ but also supported NZVI and composited NZVI are the interesting alternatives to enhance $\mathrm{Cr}(\mathrm{VI})$ removal efficiency (Fu et al. 2016; Li et al. 2016; Toli et al. 2016; Wu et al. 2015).

A mixture of NZVI and silica $\left(\mathrm{SiO}_{2}\right)$ was reported to be effective for $\mathrm{Cr}(\mathrm{VI})$ reduction (Oh et al. 2007; Powell et al. 1995). However, the mixture was not adhered together resulting in NZVI allowed the direct adsorption of precipitated $\mathrm{Cr}$ (III) onto its surface. Consequently, the available reactive surface area and $\mathrm{Cr}(\mathrm{VI})$ reduction rate of NZVI was decreased. As a result, synthesized method as well as synthesized condition of silica-supported NZVI $\left(\mathrm{NZVI} / \mathrm{SiO}_{2}\right.$ ) is probably a key factor in improving the efficiency of $\mathrm{Cr}(\mathrm{VI})$ removal. It is, therefore, necessary to determine the condition of $\mathrm{NZVI} / \mathrm{SiO}_{2}$ synthesis that provides the highest $\mathrm{Cr}(\mathrm{VI})$ removal efficiency.

Box-Behnken design (BBD) has been used as a tool to determine optimal condition for desired responses in diverse studies, such as the optimization of dye removal by the laccase-mediator system (Dassi et al. 2012), Zn extraction from pyrometallurgical sludge in the steel manufacturing industry (Mocellin et al. 2015) and an azo dye batch adsorption (Tripathi et al. 2009). In addition, it was applied to optimize photocatalytic degradation system of paraquat (Tantriratna et al. 2011) and preparation of Fe-ZnO catalyst used for 2,4-dichlorophenol degradation (Kiattisaksiri et al. 2014). These studies confirmed that BBD could assist to disclose the optimum of each parameter by maximizing the response variables, and was suitable for optimizing the $\mathrm{NZVI} / \mathrm{SiO}_{2}$ synthesized condition in this study.

From previous study, some important synthesized condition parameters influenced the property and reducing activity of NZVI was reported. Agitation speed of $100 \mathrm{rpm}$ compared with that of $300 \mathrm{rpm}$ was investigated in mixing $\mathrm{FeCl}_{3}$ solution and $\mathrm{NaBH}_{4}$ droplets to synthesize NZVI (Tanboonchuy et al. 2012). It was found that the higher reducing power of NZVI was obtained at the higher agitation speed because of more dispersion and higher surface area of NZVI particles. Concentration of ethanol in the ethanol/water solvent was the one of parameter concerned with NZVI synthesis (Wu et al. 2016). Absolute ethanol concentration of 0-100 vol\% showed the differences of NZVI characteristics (Wang et al. 2009). As the ethanol concentration increased, the particle size of NZVI decreased leading to its surface area increased. This was due to the lower polarity of ethanol/water solvent which encouraged the stabilized NZVI particles to disperse in the solvent and inhibited the particle agglomeration. Besides the agitation speed and concentration of ethanol; however, the amount of silica was addressed as the parameters involved in this study for $\mathrm{NZVI} / \mathrm{SiO}_{2}$ synthesis, as previously mentioned.

Thus, in this study, the BBD was applied to evaluate the optimal condition for the synthesis of $\mathrm{NZVI} / \mathrm{SiO}_{2}$. The three parameters including the ethanol concentration, the amount of silica and the agitation speed were investigated. The synthesized NZVI/SiO, were then tested for their ability to reduce a $40 \mathrm{mg} / \mathrm{L}$ of $\mathrm{Cr}(\mathrm{VI})$ solution at three different $\mathrm{pH}$ values $(4,7$ and 10$)$ in direct comparison with pristine NZVI and silica-unsupported NZVI (NZVI $\left.+\mathrm{SiO}_{2}\right)$.

\section{RESEARCH METHODS}

\section{MATERIALS}

The chemical reagents used in this study were $\mathrm{FeCl}_{3}(99 \%$, Merck), $\mathrm{NaBH}_{4}$ (> 96\%; Merck), $\mathrm{C}_{2} \mathrm{H}_{2} \mathrm{OH}(99.99 \%$, RCI Labscan) and $\mathrm{SiO}_{2}$ extracted from rice husk (Tantriratna et al. 2011). The Cr(VI) stock solution was prepared by 
dissolving $\mathrm{K}_{2} \mathrm{Cr}_{2} \mathrm{O}_{7}$ (99-100\%, J.T. Baker) into deionized water (18.2 M $\Omega$, Mill-Q).

\section{SYNTHESIS METHOD OF NZVI/SiO 2 AND NZVI $+\mathrm{SiO}_{2}$} $\mathrm{NZVI} / \mathrm{SiO}_{2}$ and $\mathrm{NZVI}+\mathrm{SiO}_{2}$ were synthesized by in-situ and ex-situ colloidal impregnation method, respectively. For the in-situ synthesis, $\mathrm{SiO}_{2}$ was mixed with $\mathrm{FeCl}_{3}$ in ethanol/ water sovent for $7 \mathrm{~h}$ with vigorous stirring. Then, it was added by $\mathrm{NaBH}_{4}$ solution $(0.25 \mathrm{M}, 50 \mathrm{~mL})$ at pumping rate of $10 \mathrm{~mL} / \mathrm{min}$. The mixture was stirred for $30 \mathrm{~s}$ after completion of $\mathrm{NaBH}_{4}$ addition. The $\mathrm{NZVI} / \mathrm{SiO}_{2}$ occurred in the mixture was separated using a magnet and then applied immediately to examine its $\mathrm{Cr}(\mathrm{VI})$ removal efficiency. For ex-situ method, $\mathrm{SiO}_{2}$ was not mixed with $\mathrm{FeCl}_{3}$ in the first step, but added after NZVI synthesis. The material obtained from ex-situ method was named as $\mathrm{NZVI}+\mathrm{SiO}_{2}$.

\section{BOX-BEHNKEN STATISTICAL DESIGN}

In order to optimize synthesized condition of the NZVI/ $\mathrm{SiO}_{2}$ the 3-level 3-factor BBD was calculated to design the experiment and analyze the experimental data for validating the independent variables which affect to the $\mathrm{Cr}(\mathrm{VI})$ removal efficiency. The highest $\mathrm{Cr}(\mathrm{VI})$ removal efficiency was evaluated by BBD in a range of independent variables limits. The independent variables included $\mathrm{X}_{1}=$ ethanol concentration $(0,50$ and $100 \mathrm{vol} \%), X_{2}=$ amount of silica $(0.025,0.075$ and $0.125 \mathrm{~g})$ and $\mathrm{X}_{3}=$ agitation speed $(100,250$ and $400 \mathrm{rpm})$. The set up range values of the independent variables were created as low $(-1)$, middle (0) and high (+1). The BBD generated 17 different synthesized conditions of the $\mathrm{NZVI} / \mathrm{SiO}_{2}$ samples used for 17 experimental runs of $\mathrm{Cr}(\mathrm{VI})$ removal as shown in Table 1. Analysis of variance (ANOVA) for a response surface quadratic model was used to approximate statistical relationship of independent variables.

\section{CHARACTERIZATION OF NZVI/SiO}

Both fresh and spent NZVI and $\mathrm{NZVI} / \mathrm{SiO}_{2}$ were analyzed for their crystallinity phases by X-ray diffraction (XRD) instrument (Model D8 Advance, Bruker AXs, Germany). The morphology of the materials was characterized by scanning electron microscopy with energy dispersive X-ray spectroscopy (SEM-EDX) technique (S-3000N, Hitachi, Japan). Additionally, the Brunauer-Emmett-Teller (BET) analysis of nitrogen adsorption/desorption (NOVA 1200e, Quantachrome, USA) was used to measure the specific surface area of the fresh NZVI, NZVI/ $\mathrm{SiO}_{2}$ and NZVI $+\mathrm{SiO}_{2}$.

\section{BATCH EXPERIMENTS FOR CR(VI) REMOVAL}

Synthetic wastewater was prepared with an initial $\mathrm{Cr}(\mathrm{VI})$ concentration of $40 \mathrm{mg} / \mathrm{L}$ in $500 \mathrm{~mL}$ to which $0.1 \mathrm{~g}$ of $\mathrm{NZVI} / \mathrm{SiO}_{2}$ was then introduced into the reaction beaker. Batch experiment was performed under $200 \mathrm{rpm}$ at $30^{\circ} \mathrm{C}$. At $40 \mathrm{~min}, 20 \mathrm{~mL}$ of the synthetic $\mathrm{Cr}(\mathrm{VI})$ wastewater was collected and measured by UV-vis spectrophotometer (V630 , Jasco, Germany) at $\lambda_{\max }=540 \mathrm{~nm}$ via colorimetric method. The percentage of $\mathrm{Cr}(\mathrm{VI})$ removal efficiency was applied to BBD and ANOVA. Then, the $\mathrm{NZVI} / \mathrm{SiO}_{2}$ experimental run which provided the optimal synthesized condition and the highest $\mathrm{Cr}(\mathrm{VI})$ removal efficiency was tested in the same manner at initial $\mathrm{Cr}(\mathrm{VI})$ solution $\mathrm{pH} 4$, 7 and 10 to compare with NZVI and NZVI $+\mathrm{SiO}_{2}$.

\section{RESULTS AND DISCUSSION}

\section{OPTIMIZATION OF NZVI/SiO 2 SYNTHESIZED CONDITION}

The NZVI/SiO 2 was synthesized by modifying the procedure described by Zhang et al. (2011). In this study, three independent variables including ethanol concentration, amount of silica and agitation speed were investigated in

TABLE 1. Combinatorial optimization of $\mathrm{NZVI} / \mathrm{SiO}_{2}$ synthesis for $\mathrm{Cr}(\mathrm{VI})$ removal (controlled condition: $\mathrm{Cr}(\mathrm{VI})$ initial concentration $=40 \mathrm{mg} / \mathrm{L}, \mathrm{NZVI} / \mathrm{SiO}_{2}=0.1 \mathrm{~g} / 500 \mathrm{~mL}$, sampling time $=40 \mathrm{~min}$ and temperature $=30^{\circ} \mathrm{C}$ )

\begin{tabular}{|c|c|c|c|c|c|}
\hline \multicolumn{4}{|c|}{ Independent variables (determined by BBD) } & \multicolumn{2}{|c|}{ Results (Cr(VI) removal (\%)) } \\
\hline Run order & $\begin{array}{c}\text { Ethanol concentration } \\
(\mathrm{vol} \%)\end{array}$ & $\begin{array}{l}\text { Amount of } \\
\text { silica }(g)\end{array}$ & $\begin{array}{l}\text { Agitation speed } \\
(\mathrm{rpm})\end{array}$ & Experimental & $\begin{array}{c}\text { Predicted } \\
\text { (from equation (6)) }\end{array}$ \\
\hline 1 & 0 & 0.075 & 400 & 46.17 & 43.73 \\
\hline 2 & 50 & 0.125 & 100 & 47.96 & 48.00 \\
\hline 3 & 50 & 0.125 & 400 & 32.68 & 36.56 \\
\hline 4 & 0 & 0.025 & 250 & 37.82 & 30.69 \\
\hline 5 & 100 & 0.075 & 100 & 89.63 & 78.35 \\
\hline 6 & 0 & 0.075 & 100 & 48.86 & 55.17 \\
\hline 7 & 50 & 0.075 & 250 & 63.82 & 61.04 \\
\hline 8 & 50 & 0.025 & 400 & 41.04 & 36.56 \\
\hline 9 & 50 & 0.075 & 250 & 62.11 & 61.04 \\
\hline 10 & 50 & 0.075 & 250 & 61.45 & 61.04 \\
\hline 11 & 50 & 0.025 & 100 & 45.60 & 48.00 \\
\hline 12 & 50 & 0.075 & 250 & 59.20 & 61.04 \\
\hline 13 & 100 & 0.025 & 250 & 58.07 & 53.87 \\
\hline 14 & 100 & 0.125 & 250 & 43.26 & 53.87 \\
\hline 15 & 0 & 0.125 & 250 & 31.82 & 30.69 \\
\hline 16 & 50 & 0.075 & 250 & 61.71 & 61.04 \\
\hline 17 & 100 & 0.075 & 400 & 66.43 & 66.91 \\
\hline
\end{tabular}


terms of their effects upon the resultant of $\mathrm{Cr}(\mathrm{VI})$ removal efficiency. The experimental runs with respect to $\mathrm{NZVI} / \mathrm{SiO}_{2}$ synthesized conditions were designed by BBD. With BBD, the experimental and predicted $\mathrm{Cr}(\mathrm{VI})$ removal efficiency is given in Table 1. The significant changes in those parameters were then evaluated by ANOVA. A quadratic regression model was found to fit reasonably to the experimental results. In Figure 1(a), the plot of the residuals against the percentage of $\mathrm{Cr}(\mathrm{VI})$ removal collected from all experiments mostly fell on the reference diagonal line. Thus, the results fitted with a normal distribution could verify the assumption of ANOVA. In Figure 1(b), the analysis of ANOVA residuals on the fitted values showed a somewhat scattered and non-specific distribution away from zero. This indicated the variance of the residuals was constant leading to the validation of the ANOVA.

The relationship of the ethanol concentration, amount of silica and agitation speed to the percentage of $\mathrm{Cr}(\mathrm{VI})$ removal at $30^{\circ} \mathrm{C}$ is shown in Figure 2. The optimized condition for $\mathrm{Cr}(\mathrm{VI})$ removal appeared to be ethanol concentration of 90-100 vol\%, silica amount of 0.07$0.08 \mathrm{~g}$ and agitation speed of 100-120 rpm. Besides the contour and surface plots for $\mathrm{Cr}(\mathrm{VI})$ removal, the main effects of the independent variables are presented clearly in Figure 3. It was showed that the ethanol concentration of $100 \%$, silica amount of $0.075 \mathrm{~g}$ and agitation speed of $100 \mathrm{rpm}$ were the most effective synthesized condition for $\mathrm{Cr}(\mathrm{VI})$ removal. Because ethanol provides lower polarity than water, it can be used to stabilize the NZVI, which is neutral, during the synthesis. However, aggregation of the NZVI is rarely formed in the lower polar solvent (Wang et al. 2009; Wu et al. 2016) leading to the improvement of $\mathrm{Cr}(\mathrm{VI})$ removal efficiency by $\mathrm{NZVI} / \mathrm{SiO}_{2}$ synthesized in the ethanol/water solvent. On the other hand, while silica is capable of directly absorbing the precipitate of $\mathrm{Cr}(\mathrm{III})$, it also releases a proton from the silanol group (Oh et al. 2007) that can increase the solubility of the precipitated $\mathrm{Cr}(\mathrm{III})$. Thus, the inclusion of higher proportion of silica reduced the $\mathrm{Cr}(\mathrm{VI})$ removal level. For agitation speed, it was observed that the resulting size of the NZVI particle is smaller at a high agitation, which implies a likely increased adsorption surface on the NZVI particles (Tanboonchuy et al. 2012). However, the decreased particle size and increased total surface area per unit mass of nanoparticles may result in some of the surfaces not being fully coated by silica during the synthesis. Therefore, the low agitation speed was still more suitable than the high agitation speed.

\section{CHARACTERISTICS OF NZVI/SiO}

The NZVI and NZVI/SiO 2 were synthesized under the optimal condition determined by BBD. The materials were characterized by XRD, SEM-EDX and BET surface area.

The XRD patterns of fresh and spent NZVI and NZVI/ $\mathrm{SiO}_{2}$ are presented in Figure 4. The peaks at $2 \theta$ of $44.55^{\circ}$ and $64.85^{\circ}$ confirmed the existing of $\mathrm{Fe}^{0}$ and the successful synthesis of NZVI and $\mathrm{NZVI} / \mathrm{SiO}_{2}$ (Wang et al. 2009; Wu et al. 2016). After $60 \mathrm{~min}$ of $\mathrm{Cr}(\mathrm{VI})$ removal, the peaks of the spent NZVI and $\mathrm{NZVI} / \mathrm{SiO}_{2}$ demonstrated the NZVI corrosion products including magnetite $\left(\mathrm{Fe}_{3} \mathrm{O}_{4}\right)$, maghemite $\left(\mathrm{Fe}_{2} \mathrm{O}_{3}\right)$ and lepidocrocite $(\mathrm{FeOOH})$ (Shih et al. 2015; Zhou et al. 2015). The intensity of the peak at $44.55^{\circ}$ was lower in the spent NZVI than that in the spent $\mathrm{NZVI} / \mathrm{SiO}_{2}$ (Shih et al. 2015). It was due to the reaction between NZVI and $\mathrm{Cr}(\mathrm{VI})$ that formed the $\mathrm{Cr}$ (III) precipitate and resulted in a decreased level of available surface area and active sites on the NZVI. In contrast, for the $\mathrm{NZVI} / \mathrm{SiO}_{2}$, the $\mathrm{Cr}(\mathrm{III})$ precipitate can form together with the $\mathrm{SiO}_{2}$ component resulting in an increase of the remaining unreacted surface of the NZVI, which was congruent with the previously reported (Kohn et al. 2005; Vikesland et al. 2003).

The SEM analysis, in Figure 5, shows that the NZVI had a higher degree of particle agglomeration compared to that for $\mathrm{NZVI} / \mathrm{SiO}_{2}$. The addition of $\mathrm{SiO}_{2}$ to the NZVI resulted in an increased dispersion of the NZVI particles which in turn provided a higher contact area between NZVI and $\mathrm{Cr}(\mathrm{VI})$. In addition, the EDX profiles showed that the major elemental components were $\mathrm{O}, \mathrm{Cl}, \mathrm{Fe}$ and $\mathrm{Si}$ for the $\mathrm{NZVI} / \mathrm{SiO}_{2}$ sample (Wu et al. 2016) except $\mathrm{Cl}$ originated from the $\mathrm{FeCl}_{3} \cdot 6 \mathrm{H}_{2} \mathrm{O}$ as a precursor of the NZVI synthesis.
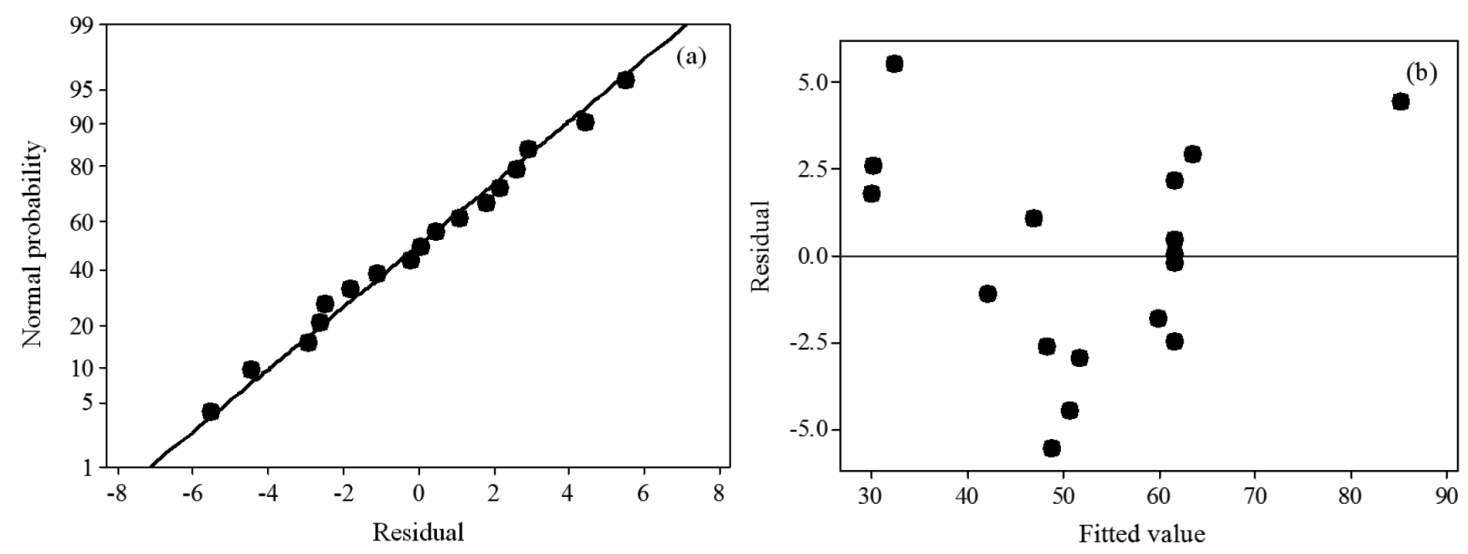

FIGURE 1. (a) Plot of normal probability and residual and (b) residual versus fitted value plot

(Response is the percentage of $\mathrm{Cr}(\mathrm{VI})$ removal) 

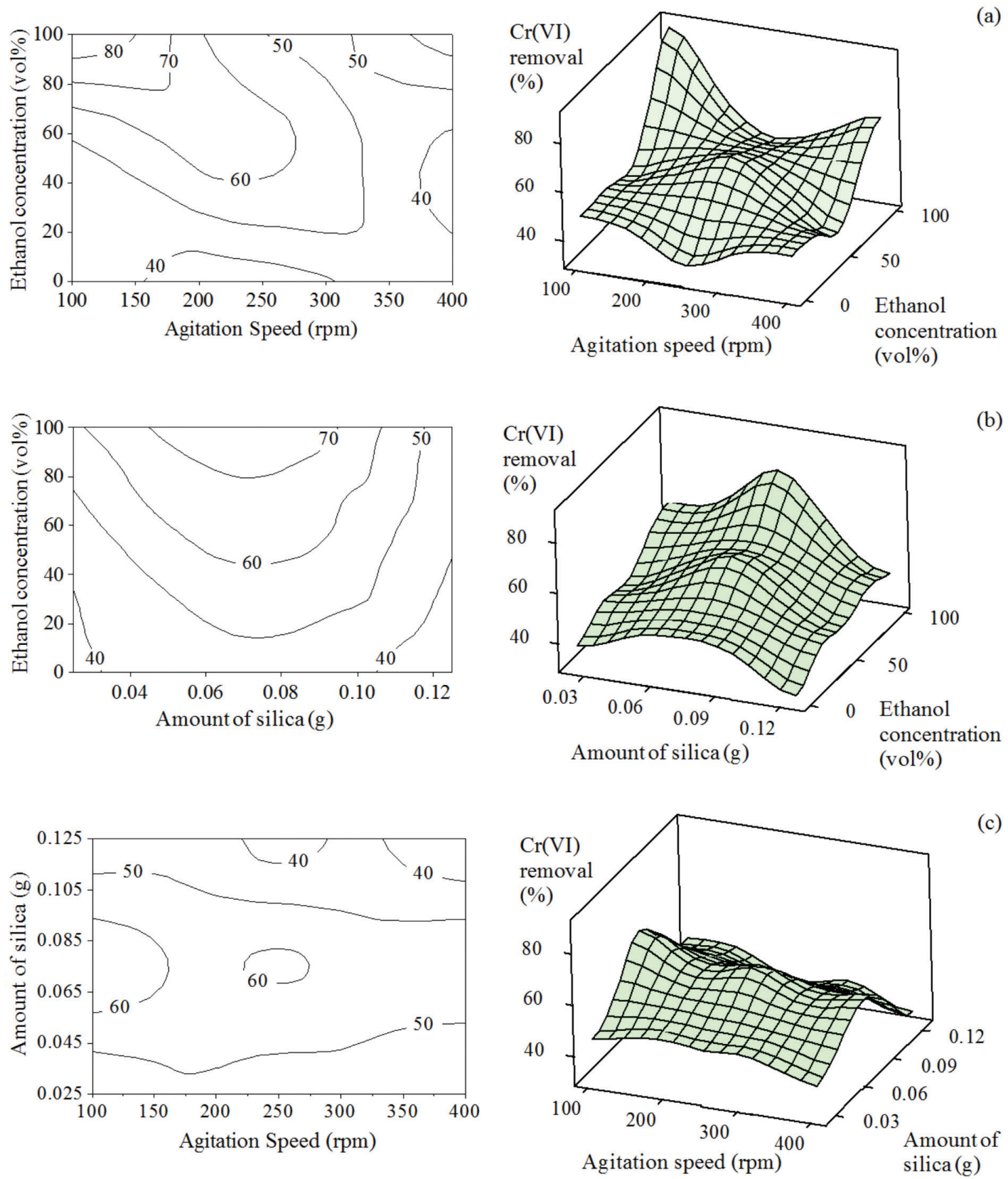

FIGURE 2. Contour and surface plots for $\mathrm{Cr}(\mathrm{VI})$ removal on the effects of (a) ethanol concentration and agitation speed, (b) ethanol concentration and amount of silica and (c) amount of silica and agitation speed

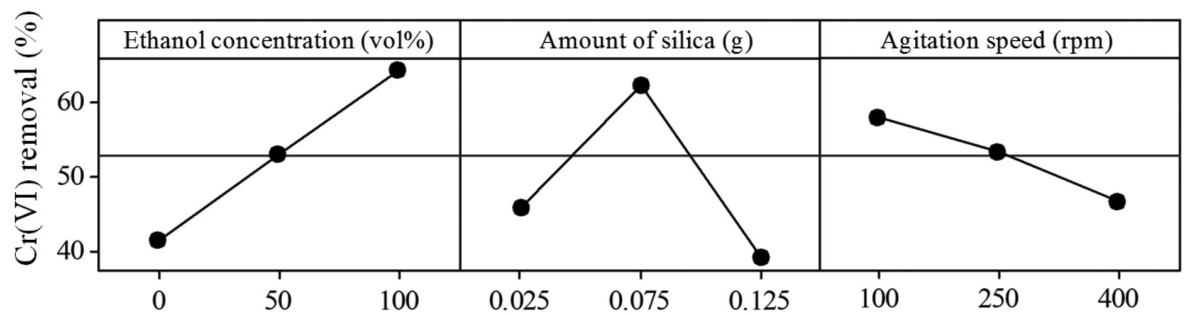

FIGURE 3. Main effect plots for $\mathrm{Cr}(\mathrm{VI})$ removal (controlled condition: $\mathrm{Cr}(\mathrm{VI})$ initial concentration $=40 \mathrm{mg} / \mathrm{L}$, NZVI/ $\mathrm{SiO}_{2}=0.1 \mathrm{~g} / 500 \mathrm{~mL}$, sampling time $=40 \mathrm{~min}$ and temperature $=30^{\circ} \mathrm{C}$ ) 


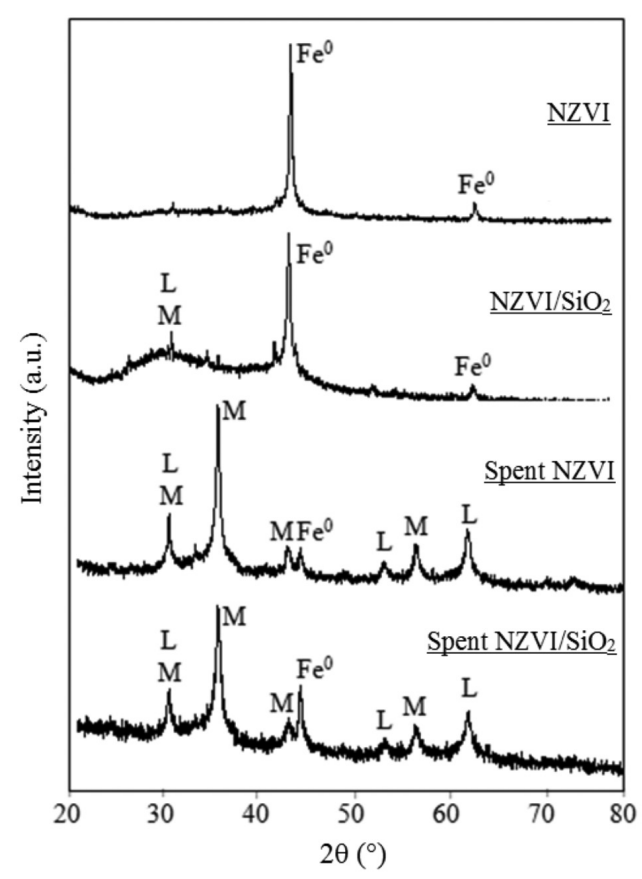

FIGURE 4. XRD patterns of NZVI, NZVI/SiO ${ }_{2}$, spent NZVI and spent $\mathrm{NZVI} / \mathrm{SiO}_{2}$ $\left(\mathrm{M}=\right.$ magnetite $\left(\mathrm{Fe}_{3} \mathrm{O}_{4}\right)$ and/or maghemite $\left(\mathrm{Fe}_{2} \mathrm{O}_{3}\right)$ and $\mathrm{L}=$ lepidocrocite $\left.(\mathrm{FeOOH})\right)$

The BET results showed that the specific surface areas of the NZVI and NZVI/SiO, were 12.35 and 8.89 $\mathrm{m}^{2} / \mathrm{g}$, respectively, while that of $\mathrm{SiO}_{2}$ was $240.12 \mathrm{~m}^{2} / \mathrm{g}$. The surface areas of the NZVI and $\mathrm{NZVI} / \mathrm{SiO}_{2}$ tended to insignificantly different by this physical property.

\section{QUADRATIC REGRESSION MODEL}

From ANOVA in Table 2, an approximate function of the $\mathrm{Cr}(\mathrm{VI})$ removal efficiency based on the quadratic regression model is derived as presented in (5);

$$
\begin{aligned}
\mathrm{Y}= & 59.66+11.59 \mathrm{X}_{1}-3.35 \mathrm{X}_{2}-5.72 \mathrm{X}_{3}+ \\
& 2.02 \mathrm{X}_{1}^{2}-18.93 \mathrm{X}_{2}^{2}+1.1 \mathrm{X}_{3}^{2}-2.2 \mathrm{X}_{1} * \mathrm{X}_{2} \\
& -5.13 \mathrm{X}_{1} * \mathrm{X}_{3}-2.68 \mathrm{X}_{2} * \mathrm{X}_{3},
\end{aligned}
$$

where $\mathrm{Y}$ is the predicted percentage of $\mathrm{Cr}(\mathrm{VI})$ removal; and $\mathrm{X}_{1}, \mathrm{X}_{2}$, and $\mathrm{X}_{3}$ represent the ethanol concentration, amount of silica and agitation speed, respectively. The correlation between the observed values and those predicted from (5) was high, with a coefficient of determination $\left(\mathrm{R}^{2}\right)$ of 0.917 . However, only the ethanol concentration $\left(\mathrm{X}_{1}\right)$, agitation speed $\left(\mathrm{X}_{3}\right)$ and the interaction between the amount of silica and the amount of silica $\left(\mathrm{X}_{2}^{2}\right)$ were significant. The ANOVA of the response surface reduced quadratic model which excluded the terms of the insignificant factors is shown in Table 3. The final equation obtained in terms of the significant factors is given in (6).

$$
\mathrm{Y}=61.04+11.59 \mathrm{X}_{1}-5.72 \mathrm{X}_{3}-18.76 \mathrm{X}_{2}^{2} \text {. }
$$

The ANOVA result for the $\mathrm{Cr}(\mathrm{VI})$ removal showed an F-value of 22.43. The model represents the significant factors that affect the response as there is only a $0.01 \%$ chance that is due to noise and insignificant lack of fit of F-value (1.29) related to the pure error. Thus, the model shown in (6) can be used to reasonably estimate the percentage $\mathrm{Cr}(\mathrm{VI})$ removal under these conditions. The predicted values for $\mathrm{Cr}(\mathrm{VI})$ removal by $\mathrm{NZVI} / \mathrm{SiO}_{2}$ were accordingly calculated, as shown in Table 1, while Figure 6 shows the close agreement between the experimental values and the predicted values from (6) with $\mathrm{R}^{2}=0.8381$.

\section{COMPARISON OF Cr(VI) REMOVAL PERFORMANCE}

The removal of $\mathrm{Cr}(\mathrm{VI})$ from solution at $30^{\circ} \mathrm{C}$ by the $\mathrm{NZVI} / \mathrm{SiO}_{2}$, along with that for $\mathrm{NZVI}+\mathrm{SiO}_{2}$ and the pure NZVI, at $\mathrm{pH} 4,7$ and 10 is shown in Figure 7. At pH 4, the pure NZVI gave the highest percentage of $\mathrm{Cr}(\mathrm{VI})$ removal (94.37\%) while the $\mathrm{NZVI} / \mathrm{SiO}_{2}$ and $\mathrm{NZVI}+\mathrm{SiO}_{2}$ did not exhibit any significant removal. In contrast, the NZVI/ $\mathrm{SiO}_{2}$ showed the highest percentage of $\mathrm{Cr}(\mathrm{VI})$ removal with 98 and $94.41 \%$ at $\mathrm{pH} 7$ and 10, respectively, within $60 \mathrm{~min}$ whereas the removal efficiency of $\mathrm{Cr}(\mathrm{VI})$ by the pure NZVI were decreased.

The reported $\mathrm{pH}_{\mathrm{pzc}}$ for the synthesized NZVI is 7.8 (Li et al. 2008; Tanboonchuy et al. 2011). At a solvent $\mathrm{pH}$ above 7.8 , the pristine NZVI surface has a negative charge and $\mathrm{CrO}_{4}^{2-}$ is formed. The same charge creates an electrostatic repulsion that results in a decreased removal of $\mathrm{Cr}(\mathrm{VI})$. In addition, the $\mathrm{Cr}(\mathrm{VI})$ can be reduced to $\mathrm{Cr}(\mathrm{III})$ by NZVI and then precipitated in the form of $\mathrm{Cr}(\mathrm{OH})_{3}$. When the solution $\mathrm{pH}$ is above 7 , the $\mathrm{Cr}(\mathrm{III})$ is co-precipitated with $\mathrm{Fe}(\mathrm{OH})_{3}$, as shown in (3) and (4) 

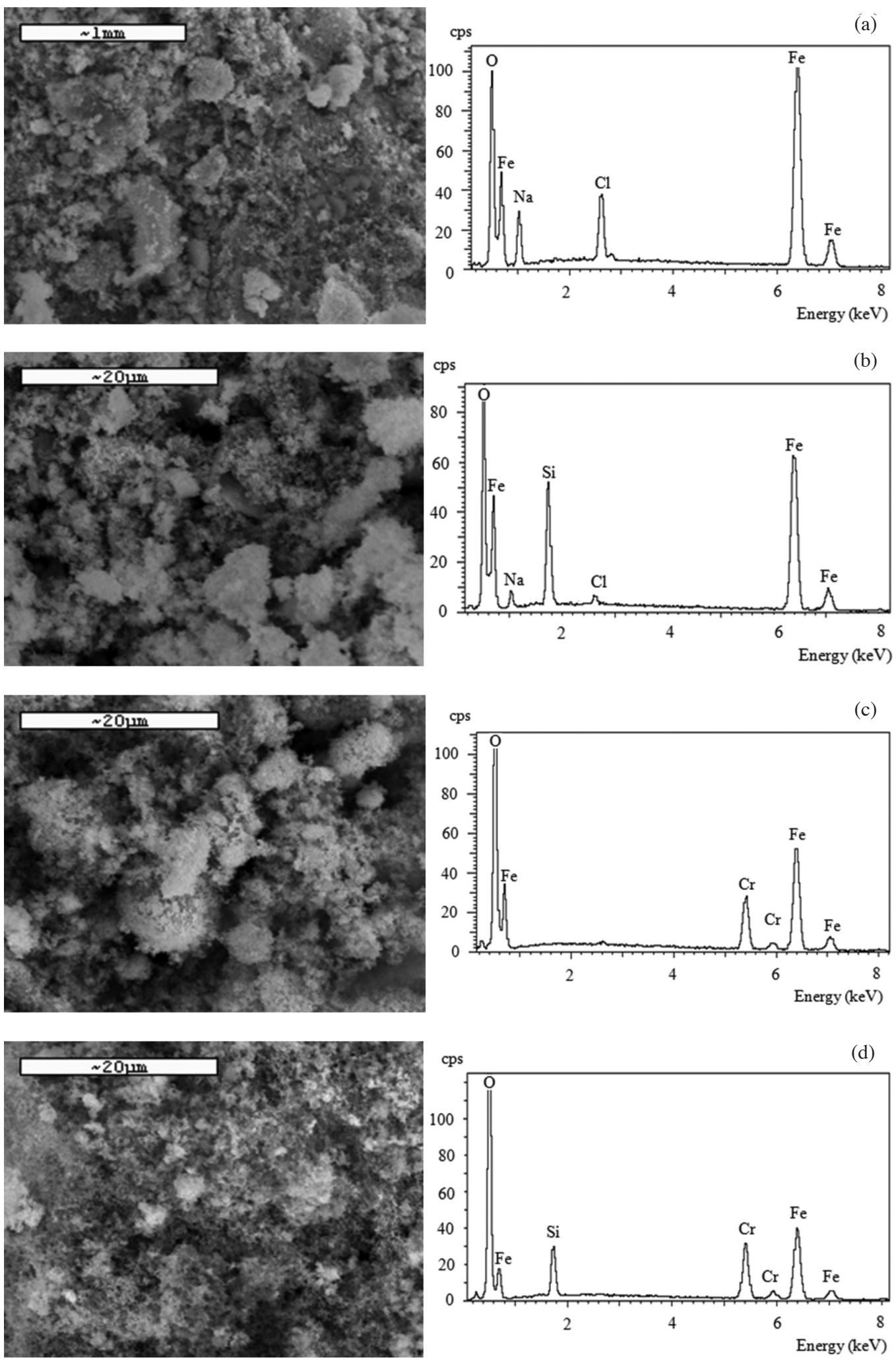

FIGURE 5. SEM images and EDX analysis of (a) NZVI (b) NZVI/SiO ,

(c) spent NZVI and (d) spent $\mathrm{NZVI} / \mathrm{SiO}_{2}$

(Astrup et al. 2000; Blowes et al. 1997; Powell \& Puls 1997). Therefore, the $\mathrm{Cr}$ (III) can be adsorbed onto the NZVI's surface without the adsorption of $\mathrm{Cr}(\mathrm{OH})_{3}$ and
$\mathrm{Fe}(\mathrm{OH})_{3}$ by $\mathrm{SiO}_{2}$. This led to the inferiority of the pristine $\mathrm{NZVI}$ to remove $\mathrm{Cr}(\mathrm{VI})$ comparing to $\mathrm{NZVI} / \mathrm{SiO}$, and $\mathrm{NZVI}+\mathrm{SiO}_{2}$. 
TABLE 2. ANOVA for response surface quadratic model

\begin{tabular}{|c|c|c|c|}
\hline Term & Coefficient & F-Value & P-value \\
\hline Constant & 59.66 & - & - \\
\hline Ethanol concentration (vol. \%) $\left(\mathrm{X}_{1}\right)$ & 11.59 & 26.89 & 0.0013 \\
\hline Amount of silica $(g)\left(X_{2}\right)$ & -3.35 & 2.25 & 0.1774 \\
\hline Agitation speed (rpm) $\left(\mathrm{X}_{3}\right)$ & -5.72 & 6.54 & 0.0377 \\
\hline Ethanol concentration (vol. \%)*Ethanol concentration (vol. \%) $\left(\mathrm{X}_{1}^{*} \mathrm{X}_{1}\right)$ & 2.02 & 0.49 & 0.5333 \\
\hline Amount of silica $(\mathrm{g}) *$ Amount of silica $(\mathrm{g})\left(\mathrm{X}_{2} * \mathrm{X}_{2}\right)$ & -18.93 & 2.63 & 0.0005 \\
\hline Agitation speed $(\mathrm{rpm}) *$ Agitation speed $(\mathrm{rpm})\left(\mathrm{X}_{3} * \mathrm{X}_{3}\right)$ & 1.10 & 0.72 & 0.7325 \\
\hline Ethanol concentration $\left(\right.$ vol. \%)*Amount of silica $(g)\left(\mathrm{X}_{1} * \mathrm{X}_{2}\right)$ & -2.20 & 0.43 & 0.5084 \\
\hline Ethanol concentration $($ vol. $\%) *$ Agitation speed $(\mathrm{rpm})\left(\mathrm{X}_{1} * \mathrm{X}_{3}\right)$ & -5.13 & 37.77 & 0.1488 \\
\hline Amount of silica $(\mathrm{g}) *$ Agitation speed $(\mathrm{rpm})\left(\mathrm{X}_{2} * \mathrm{X}_{3}\right)$ & -2.68 & 0.13 & 0.4245 \\
\hline Model & & 8.60 & 0.0049 \\
\hline Lack of fit & & 1.33 & 0.3825 \\
\hline \multicolumn{4}{|l|}{ R-squared $=0.9171$} \\
\hline Adj R-squared $=0.8104$ & & & \\
\hline
\end{tabular}

TABLE 3. ANOVA for the response surface reduced quadratic model

\begin{tabular}{lccc}
\hline \multicolumn{1}{c}{ Term } & Coefficient & F-Value & P-value \\
\hline Constant & 61.04 & - & - \\
Ethanol concentration $\left(\right.$ vol. \%) $\left(\mathrm{X}_{1}\right)$ & 11.59 & 25.58 & 0.0002 \\
Agitation speed $(\mathrm{rpm})\left(\mathrm{X}_{3}\right)$ & -5.72 & 6.22 & 0.0269 \\
Amount of silica $(\mathrm{g}) *$ Amount of silica $(\mathrm{g})\left(\mathrm{X}_{2}^{*} \mathrm{X}_{2}\right)$ & -18.76 & 35.48 & $<0.0001$ \\
& & & \\
Model & & 22.43 & 0.0001 \\
Lack of fit & & 1.29 & 0.4326 \\
R-squared $=0.8381$ & & & \\
\hline
\end{tabular}

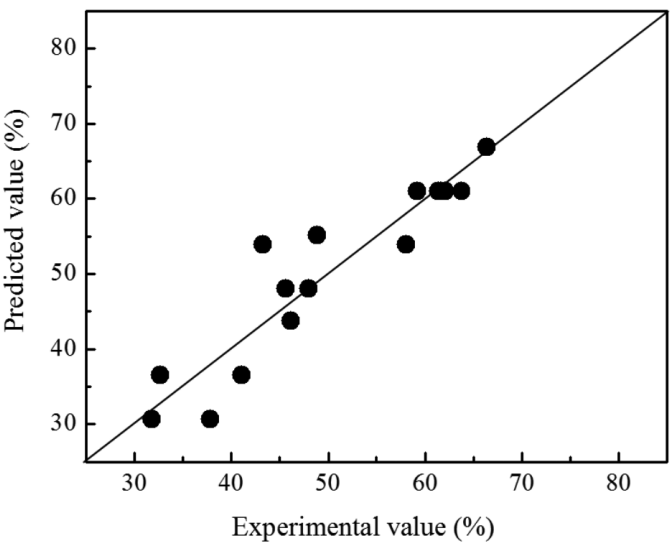

FIGURE 6. Parity plot of actual and predicted $\mathrm{Cr}(\mathrm{VI})$ removal $\left(\mathrm{R}^{2}=0.8381\right)$

\section{PROPOSED MECHANISM OF CR(VI) REMOVAL BY NZVI/SiO}

The proposed mechanism of $\mathrm{Cr}(\mathrm{VI})$ removal over NZVI/ $\mathrm{SiO}_{2}$ is shown in Figure 8. Firstly, the $\mathrm{CrO}_{4}^{2-}$ was reduced by NZVI to form $\mathrm{Cr}^{3+}, \mathrm{Fe}^{3+}$ and $\mathrm{OH}^{-}$ions. Then, under the alkaline environment of $\mathrm{OH}^{-}$, the $\mathrm{Cr}^{3+}$ and $\mathrm{Fe}^{3+}$ were readily precipitated in the forms of $\mathrm{Cr}(\mathrm{OH})_{3(\mathrm{~s})}$ and $\mathrm{Fe}(\mathrm{OH})_{3(\mathrm{~s})}$. Moreover, the $\mathrm{Cr}^{3+}, \mathrm{Fe}^{3+}$ and $\mathrm{OH}^{-}$ions could possibly combine simultaneously to form $\mathrm{Cr}_{\mathrm{x}} \mathrm{Fe}_{1-\mathrm{x}}(\mathrm{OH})_{3(\mathrm{~s})}$ complexes (Wu et al. 2015). All the precipitated species can directly adsorb on the $\mathrm{SiO}_{2}$ surface, as confirmed by the EDX profiles (Figure 5). Since the surface availability of $\mathrm{SiO}_{2}$ is considerably higher than that of NZVI, the precipitation of the various $\mathrm{Cr}(\mathrm{OH})_{3(\mathrm{~s})}, \mathrm{Fe}(\mathrm{OH})_{3(\mathrm{~s})}$ and $\mathrm{Cr}_{x} \mathrm{Fe}_{1-x}(\mathrm{OH})_{3(\mathrm{~s})}$ complexes would mainly take place on the $\mathrm{SiO}_{2}$ surface. With less precipitation on the NZVI surface, the NZVI accordingly retained a higher level of available active sites for further $\mathrm{Cr}(\mathrm{VI})$ removal, as shown in steps (1)-(3) in Figure 8.

\section{CONCLUSION}

The NZVI/SiO 2 was synthesized via colloidal impregnation method. The optimal synthesized condition of $\mathrm{NZVI} / \mathrm{SiO}_{2}$ was designed, analyzed and validated by BBD and ANOVA. The ethanol concentration, amount of silica and agitation speed influenced the efficiency of the $\mathrm{NZVI} / \mathrm{SiO}_{2}$ to remove $\mathrm{Cr}(\mathrm{VI})$ and were set as the independent variables. The morphology of $\mathrm{NZVI} / \mathrm{SiO}_{2}$ can be significantly controlled by effects of ethanol concentration and agitation speed. The optimal condition for the synthesis of $\mathrm{NZVI} / \mathrm{SiO}_{2}$ for $\mathrm{Cr}(\mathrm{VI})$ removal was $100 \mathrm{vol} \%$ of ethanol concentration, 0.075 $\mathrm{g}$ of silica amount and $100 \mathrm{rpm}$ of agitation speed. The $\mathrm{Cr}$ (VI) removal efficiency was highly obtained over the $\mathrm{NZVI} / \mathrm{SiO}_{2}$ compared to that by the pristine NZVI and NZVI 

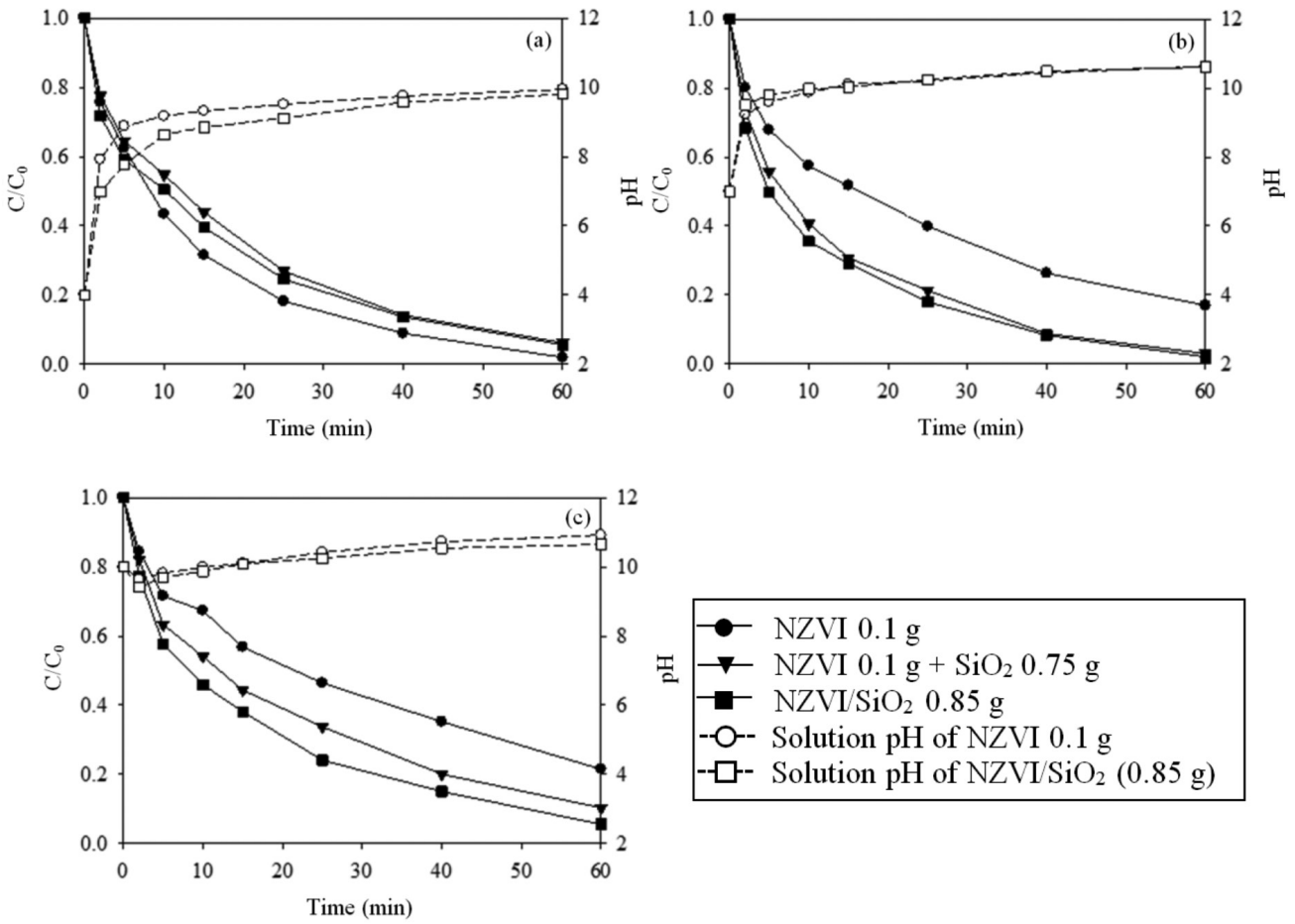

FIGURE 7. Cr(VI) removal by synthesized materials at initial $\mathrm{Cr}(\mathrm{VI})$ solution $\mathrm{pH}$ (a) 4, (b) 7, and (c) 10 (controlled condition: $\mathrm{Cr}(\mathrm{VI})$ initial concentration $=40 \mathrm{mg} / \mathrm{L}, \mathrm{NZVI} / \mathrm{SiO}_{2}=0.1 \mathrm{~g} / 500 \mathrm{~mL}$, sampling time $=40 \mathrm{~min}$ and temperature $=30^{\circ} \mathrm{C}$ )

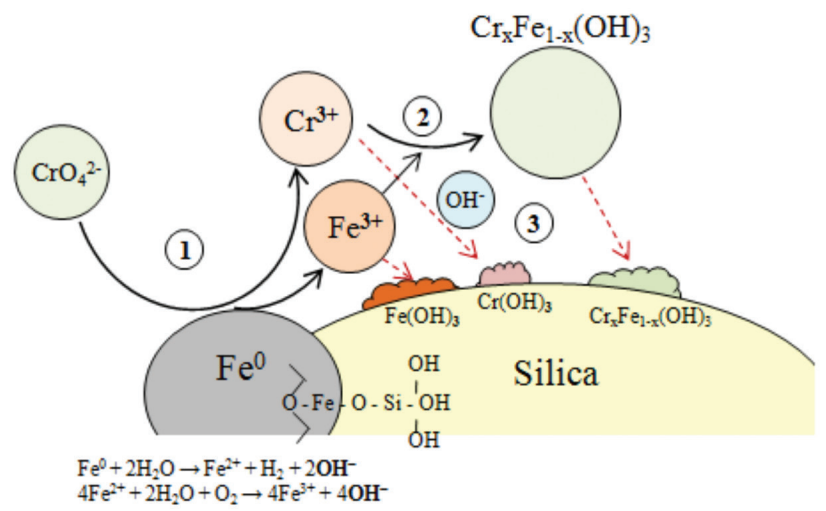

FIGURE 8. Proposed mechanism of $\mathrm{Cr}(\mathrm{VI})$ removal by $\mathrm{NZVI} / \mathrm{SiO}_{2}$

$+\mathrm{SiO}_{2}$, especially at pH 7 and 10 with 98 and $94.41 \%$ of $\mathrm{Cr}(\mathrm{VI})$ removal, respectively, at $60 \mathrm{~min}$. $\mathrm{As} \mathrm{SiO}_{2}$ played the important role on the adsorption of $\mathrm{Cr}(\mathrm{OH})_{3(\mathrm{~s})}, \mathrm{Fe}(\mathrm{OH})_{3(\mathrm{~s})}$ and $\mathrm{Cr}_{\mathrm{x}} \mathrm{Fe}_{1-\mathrm{x}}(\mathrm{OH})_{3(\mathrm{~s})}$ precipitates, which were by-product of $\mathrm{Cr}(\mathrm{VI})$ reduction, the available active sites of $\mathrm{NZVI} / \mathrm{SiO}_{2}$ were still remained for further $\mathrm{Cr}(\mathrm{VI})$ removal.

\section{ACKNOWLEDGEMENTS}

This research was sponsored by research fund from the Faculty of Engineering, Khon Kaen University, Thailand.

\section{REFERENCES}

Anderson, R.A. 1997. Chromium as an essential nutrient for humans. Regulatory Toxicology Pharmacology 26: 35-41.
Astrup,T., Stipp, S.L.S. \& Christensen, T.H. 2000. Immobilization of chromate from coal fly ash leachate using an attenuating barrier containing zero-valent iron. Environmental Science \& Technology 34: 4163-4168.

Blowes, D.W., Ptacek, C.J. \& Jambor, J.L. 1997. In situ remediation of $\mathrm{Cr}(\mathrm{VI})$ contaminated ground water using permeable reactive walls: Laboratory studies. Environmental Science \& Technology 31: 3348-3357.

Chang, L.Y. 2005. Chromate reduction in wastewater at different $\mathrm{pH}$ levels using thin iron wires-a laboratory study. Environmental Progress 24: 305-316.

Chang, L.Y. 2003. Alternative chromium reduction and heavymetal precipitation methods for industrial wastewater. Environmental Progress 22: 174-182.

Chen, S.S., Cheng, C.Y., Li, C.W., Chai, P.H. \& Chang, Y.M. 2006. Reduction of chromate from electroplating wastewater 
from $\mathrm{pH} 1$ to 2 using fluidized zero valent iron process. Journal of Hazardous Materials 142: 362-367.

Coller-Myburgh, C.V., Rensburg, L.V. \& Maboeta, M. 2014. Utilizing earthworm and microbial assays to assess the ecotoxicity of chromium mine wastes. Applied Soil Ecology 83: $258-265$

Costa, M. 2003. Potential hazards of hexavalent chromate in our drinking water. Toxicology and Applied Pharmacology 188: $1-5$.

Dassi, D., Frikha, F., Zouari, M.H., Belbahri, L., Woodward, S. \& Mechichi, T. 2012. Application of response surface methodology to optimize decolourization of dyes by the laccase-mediator system. Journal of Environmental Management 108: 84-91.

Fu, R., Yang, Y., Xu, Z., Zhang, X., Guo, X. \& Bi, D. 2015. The removal of chromium (VI) and lead (II) from groundwater using sepiolite-supported nanoscale zero-valent iron (S-NZVI). Chemosphere 138: 726-734.

Guha, S. \& Bhargava, P. 2005. Removal of chromium from synthetic plating waste by zero-valent iron and sulfatereducing bacteria. Water Environment Research 77: 411-416.

Katz, S.A. \& Salem, H. 1993. The toxicology of chromium with respect to its chemical speciation: A review. Journal of Applied Toxicology 13: 217-224.

Kiattisaksiri, P., Khamdahsag, P., Khemthong, P., Pimpha, N. \& Grisdanurak, N. 2014. Photocatalytic degradation of 2,4-dichlorophenol over $\mathrm{Fe}-\mathrm{ZnO}$ catalyst under visible light. Korean Journal of Chemical Engineering. DOI: 10.1007/ s11814-014-0379-6.

Kohn, T., Livi, K.J.T., Roberts, A.L. \& Vikesland, P.J. 2005. Longevity of granular iron in groundwater treatment processes: Corrosion product development. Environmental Science \& Technology 39: 2867-2879.

Li, X., Ai, L. \& Jiang, J. 2016. Nanoscale zerovalent iron decorated on graphene nanosheets for $\mathrm{Cr}(\mathrm{VI})$ removal from aqueous solution: Surface corrosion retard induced the enhanced performance. Chemical Engineering Journal 288: 789-797.

Li, X.Q., Cao, J. \& Zhang, W.X. 2008. Immobilization of hexavalent chromium with Iron nanoparticles: Characterizations with high resolution X-ray photoelectron spectroscopy (HR-XPS). Industrial \& Engineering Chemistry Research 47: 2131-2139.

Liu, C., Fiol, N., Poch, J. \& Villaescusa, L. 2016. A new technology for the treatment of chromium electroplating wastewater based on biosorption. Journal of Water Process Engineering 11: 143-151.

Mocellin, J., Mercier, G., Morel, J.L., Blais, J.F. \& Simonnot, M.O. 2015. Factors influencing the $\mathrm{Zn}$ and $\mathrm{Mn}$ extraction from pyrometallurgical sludge in the steel manufacturing industry. Journal of Environmental Management 158: 48-54.

Oh, Y.J., Song, H., Shin, W.S., Choi, S.J. \& Kim, Y.H. 2007. Effect of amorphous silica and silica sand on removal of chromium(VI) by zero-valent iron. Chemosphere 66: 858865 .

Padmavathy, K.S., Madhu, G. \& Haseena, P.V. 2016. A study on effects of $\mathrm{pH}$, adsorption dosage, time, initial concentration and adsorption isotherm study for removal of hexavalent chromium $(\mathrm{Cr}(\mathrm{VI}))$ from wastewater by magnetite nanoparticles. Procedia Technology 24: 585-594.

Powell, R.M. \& Puls, R.W. 1997. Proton generation by dissolution of intrinsic or augmented aluminosilicate minerals for in situ contaminant remediation by zero-valence-state iron. Environmental Science \& Technology 31: 2244-2251.
Powell, R.M., Puls, R.W., Hightower, S.K. \& Sabatini, D.A. 1995. Coupled iron corrosion and chromate reduction: Mechanisms for subsurface remediation. Environmental Science \& Technology 29: 1913-1922.

Sass, B.M. \& Rai, D. 1987. Solubility of amorphous chromium(III)-iron(III) hydroxide solid-solution. Inorganic Chemistry 26: 2228-2232.

Shih, Y.J., Chen, C.W., Hsia, K.F. \& Dong, C.D. 2015. Granulation for extended-release of nanoscale zero-valent iron exemplified by hexavalent chromium reduction in aqueous solution. Separation and Purification Technology 156: 1073-1081.

Tanboonchuy, V., Grisdanurak, N. \& Liao, C.H. 2012. Nitrate probe for quantifying reducing power of nanoscale zerovalent iron. Sustainable Environment Research 22: 185-191.

Tanboonchuy, V., Hsu, J.C., Grisdanurak, N. \& Liao, C.H 2011. Gas-bubbled nano zero-valent iron process for high concentration arsenate removal. Journal of Hazardous Materials 186: 2123-2128.

Tantriratan, P., Wirojanagud, W., Neramittagapong, S., Wantala, K. \& Grisdanurak, N. 2011. Optimization for UVphotocatalytic degradation of paraquat over titanium dioxide supported on rice husk silica using Box-Behnken design. Indian Journal of Chemical Technology 18: 363-371.

Toli, A., Chalastara, K., Mystrioti, C., Xenidis, A. \& Papassiopi, N. 2016. Incorporation of zero valent iron nanoparticles in the matrix of cationic resin beads for the remediation of $\mathrm{Cr}(\mathrm{VI})$ contaminated waters. Environmental Pollution 214: 419-429.

Tripathi, P., Srivastava, V.C. \& Kumar, A. 2009. Optimization of an azo dye batch adsorption parameters using Box-Behnken design. Desalination 249: 1273-1279.

Vikesland, P.J., Klausen, J., Zimmermann, H., Roberts, A.L. \& Ball, W.P. 2003. Longevity of granular iron in groundwater treatment processes: Changes in solute transport properties over time. Journal of Contaminant Hydrology 64: 3-33.

Wang, Q., Snyder, S., Kim, J. \& Choi, H. 2009. Aqueous ethanol modified nanoscale zerovalent iron in bromate reduction: Synthesis, characterization and reactivity. Environmental Science \& Technology 43: 3292-3299.

World Health Organization (WHO). 2004. Guidelines for Drinking-water Quality. 3rd ed. Recommendations. WHO, Geneva. 1: 334-335.

Wu, C., Li, C., Leng, D. \& Cui, D. 2016. Factors affecting the reductive properties of the core-shell Sio2-coated iron nanoparticles. Advances in Chemical Engineering and Science 6: 316-323.

Wu, L., Liao, L., Lv, G. \& Qin, F. 2015. Stability and pHindependence of nano-zero-valent iron intercalated montmorillonite and its application on $\mathrm{Ce}(\mathrm{VI})$ removal. Journal of Contaminant Hydrology 179: 1-9.

Yirsaw, B.D., Megharaj, M., Chen, Z. \& Naidu, R. 2016. Reduction of hexavalent chromium by green synthesized nano zero valent iron and process optimization using response surface methodology. Environmental Technology \& Innovation 5: 136-147.

Zhang, Y., Li, Y., Li, J., Hu, L. \& Zheng, X. 2011. Enhanced removal of nitrate by a novel composite: Nanoscale zero valent iron supported on pillared clay. Chemical Engineering Journal 171: 526-531.

Zhou, X., Lv, B., Zhou, Z., Li, W. \& Jing, G. 2015. Evaluation of highly active nanoscale zero-valent iron coupled with ultrasound for chromium(Vi) removal. Chemical Engineering Journal 281: 155-163. 
Praewpatra Archariyapanyakul

Department of Chemical Engineering, Faculty of Engineering

Thammasat University, Pathumthani 12120

Thailand

Bhuckchanya Pangkumhang \& Visanu Tanboonchuy*

Department of Environmental Engineering,

Faculty of Engineering

Khon Kaen University, Khon Kaen 40002

Thailand

\section{Pummarin Khamdahsag}

Environmental Research Institute

Center of Excellence on Hazardous Substance Management

Chulalongkorn University, Bangkok 10330

Thailand

Pummarin Khamdahsag

Research Unit of Site Remediation on Metals Management from Industry and Mining,

Center of Excellence on Hazardous Substance Management

Chulalongkorn University, Bangkok 10330

Thailand
Pummarin Khamdahsag \& Visanu Tanboonchuy*

Research Program of Toxic Substance Management in Mining Industry

Center of Excellence on Hazardous Substance Management

Chulalongkorn University, Bangkok 10330

Thailand

Visanu Tanboonchuy*

Research Center for Environmental and Hazardous Substance Management (EHSM)

Khon Kaen University, Khon Kaen 40002

Thailand

*Corresponding author; email: visanu@kku.ac.th

Received: 25 April 2016

Accepted: 7 September 2016 